\title{
Life-Cycle and Its Impact on the Disparity in Economic Well-Being among U.S. Sole Proprietor Households: Evidence from Two National Surveys
}

\author{
Hisham S. El-Osta ${ }^{1}$ \\ ${ }^{1}$ A Former Agricultural Economist with the Economic Research Service, United States Department of Agriculture. The \\ views expressed are those of the author and do not necessarily represent the policies or views of ERS or USDA. \\ Correspondence: Hisham S. El-Osta, E-mail: hishamelosta@ aol.com.
}

This research was supported by the U.S. Department of Agriculture, Economic Research Service.

Received: August 28, 2019

doi:10.11114/aef.v7i1.4629

\author{
Accepted: October 8, $2019 \quad$ Available online: November 27, 2019 \\ URL: https://doi.org/10.11114/aef.v7i1.4629
}

\begin{abstract}
The impact of age on the distribution of wealth among U.S. sole proprietor households is analyzed using data from two national surveys in conjunction with disparity and social welfare decomposition methods. Results show higher disparity in wealth when the household is a non-farm rather than a farm sole proprietor household. The cohort with the greatest need in terms of targeted programs is the group of farm or non-farm households headed by individuals younger than 35 .
\end{abstract}

Keywords: life-cycle, Gini index, economic disparity, social welfare decomposition

JEL Classification: G51, D14, Q12, Q18

\section{Introducation}

Published research on the economic wellbeing of farm households in the U.S. has shown that they are no longer economically disadvantaged in comparison to their non-farm counterparts. This assessment is based on the finding that the median total farm household income, since 1998, has surpassed the median income of all U.S. households (Mishra et al. 2002; El-Osta and Morehart 2008; Prager and Lyons 2018). While historically most attention, both nationally and internationally, has focused on the incomes of households, many studies have emphasized the need to evaluate economic well-being based on the extent of wealth accumulation by households or based on a combined income and annuitized wealth measure (Wolff 1990; Keister ad Moller 2000; Hill 2000; Balestra and Tonkin 2018).

The importance of the role of the life cycle as described by the age of the household head on earnings and wealth accumulation has been examined in the general economics literature (e.g., Samuelson 1958, Atkinson 1971, Ando and Modigliani 1963, Mookherjee and Shorrocks 1982, Modigliani 1986 and 1988, and Huggett 1996, among others) where the studies have posited that households will accumulate assets during their working years and use these assets to fund consumption during retirement. For farm households, the importance of incorporating life-cycle effects when examining the distribution of wealth has been noted in numerous studies since aging farmers tend to switch to less labor and capital intensive production enterprises (e.g., Haden and Johnson 1989; Batte, Jones, and Schnitkey 1990). ${ }^{1}$ A consequence of this is that older farmers tend to have different portfolios of farm assets than younger farmers, in addition to the fact that the market value attached to the current physical capital of older farmers tends to be lower than that of younger farmers.

Numerous studies have noted the presence of additional factors beyond age that contribute to the disparity in wealth. For example, a study by Gale and Scholz (1994) points to the importance of inheritance in explaining wealth differences for households in general, particularly at the upper end of the wealth distribution. Yet other studies suggest additional factors with relevance to the disparity in wealth that include education, differences in the saving behavior, precautionary motives, expertise of the labor force, and resource endowments (e.g., Browning and Lusardi 1996; Cagetti, 2003; Cagetti and De Nardi 2008).

Several studies have investigated the size and the distribution of wealth among farm families (e.g., Wunderlich 1984;

${ }^{1}$ Yet another thread of literature emphasized the importance of the life-cycle in impacting farm related decisions (e.g., spending, resource allocation, etc.), farm expansion, and patterns of exiting and/or entering into farming (Boehlje, 1973 and 1992; Gale, 1994 and 2003; Pushkarskaya and Vedenov 2009). 
Skees, Reed, and Pederson 1985; Ahearn and El-Osta 1991; El-Osta and Morehart 2002; Mishra et al., 2002; Mishra and Chang 2009). Notwithstanding the contribution of these studies, there seems to be a scarcity of literature regarding the impact of the life cycle on the disparity in farm household wealth. Given the significance of wealth to economic well-being and to social welfare (see OECD 1998), the main objective of this paper is to examine the wealth inequality of U.S. sole proprietor households -both farm and non-farm households--over the 2013 and 2016 time periods. The analysis, which allows for the measurement and for the partitioning of economic disparity and of social welfare function in the context of the life-cycle will be based on a method of decomposing welfare disparity as was initially developed by Podder (1993) and later applied, among others, by Mukhopadhaya (2002), and by El-Osta and Morehart (2009). Embedding social welfare function in the analysis builds upon the economic welfare literature (see Atkinson 1970; Dasgupta et al. 1973; Willig 1981; Shorrocks 1983) that assume that policy makers aim, depending on the chosen measure of wellbeing, for higher levels (efficiency preference) and for greater equality in the distribution of that measure (equity preference). The analysis will be based on pertinent demographic and financial information from two national databases: The Survey of Consumer Finances (SCF) and the Agricultural Resource Management Survey (ARMS). In examining the distribution of wealth among farm and non-farm sole proprietor households in 2013 and 2016, this allows for the discernment if wealth disparity has widened over the short time-period considered.

Among the main characteristics that define households in general thus is that they tend to earn more and accumulate less in wealth in the early life-stages of heads of household, with the trend reversing in the later stages of the life cycle. ${ }^{2}$ For example, and as in the case of total wealth (i.e., net worth) in the U.S., those households headed by adults under the age of 35 had a median wealth of about $\$ 11,000$ in 2016; which was about 5 percent of the median wealth of about $\$ 236,000$ for those households headed by adults aged 65 or older. $^{3}$ In terms of accumulated wealth, while the share of all the wealth held in the general population by households in the younger age group in 2016 was 2.3 percent, the share held by households in the older age group, in comparison, was at 39 percent. Similarly, farm households with operators aged 34 or younger tend to own significantly lower levels of wealth than their counterparts with operators aged 65 or older. For instance, in 2016, the median wealth of the younger-aged households was $\$ 246,000$; which was about 27 percent of the median wealth of about $\$ 900,000$ for those households with operators aged 65 or older. ${ }^{4}$ For the younger-aged farm households, while their share of all of the accumulated wealth was under 2 percent, the share held by households in the older age group, in comparison, was at about 41 percent.

\section{Data and Measurement}

Data on household wealth from the SCF and the ARMS for 2013 and 2016 provided the samples needed in the analysis. ${ }^{5}$ The SCF is a triennial cross-sectional survey of the finances of U.S. families that has been undertaken by the Board of Governors of the Federal Reserve System since 1983 (Bricker et al. 2017). Sample weights created for the SCF allow for the expansion of financial estimates to the U.S. household population level in a given survey year (see Lindamood et al. 2007).

The aim of the paper is to formulate comparable samples of farm and non-farm self-proprietor households. In the SCF, self-proprietorship status results from two questions that ask, respectively, whether the head of household is self-employed and is actively involved in the management of the business. Excluding households that operate farms along with those households where the heads have passive roles in the management of the selected businesses from the 2013 and 2016 SCF samples, and utilizing corresponding sample survey weights $\left(W_{i}\right)$, the number of sole proprietor households stood at 7.9 million and 8.3 million, respectively. In 2016, the 8.3 million sole proprietor households, while they represented 6.6 percent of all non-farm U.S. households, they disproportionately held 32.2 percent of total net worth and earned 18.0 percent of total income.

The ARMS is a national survey conducted annually by the Economic Research Service and the National Agricultural Statistics Service of the U.S. Department of Agriculture (USDA). The survey is the USDA's principal source of information on the farming practices, resource use, and economic well-being of farms and ranches in the U.S. In both 2013 and 2016, the expanded number of sole proprietor households totaled nearly 2.0 million. In comparison to non-farm sole proprietorship households, the nearly 2.0 million farm sole proprietor households in 2016 accounted for 89.5 percent of all farm households. The shares of their total owned net worth and total earned income relative to the shares held by all farm households were at 81.4 percent and 82.8 percent, respectively.

\footnotetext{
${ }^{2}$ Wealth refers to net worth as captured by the difference between a household's total assets which can be used to finance its current and future consumption needs and total liabilities.

${ }^{3}$ These statistics are for a population of households that exclude farm operator households (2016 SCF).

${ }^{4}$ These statistics are for farm operator households (2016 ARM).

${ }^{5}$ Both the SCF and the ARMS ask for the levels of household wealth for the current survey year.
} 


\section{Social Welfare Function}

The disparity in wealth $(N W)$ among farm and non-farm households is assessed using the Gini index, $G$. The advantage of using $G$ in this paper to assess the inequality in $N W$ is that it allows for measuring and, consequently, for disaggregating the following 'Bergson-Samuelson' social welfare function $(W)$ by five age cohorts as in: ${ }^{6}$

$$
W=W\left[\left(U_{1}\left(x_{1}\right), U_{2}\left(x_{2}\right), \cdots, U_{n}\left(x_{n}\right) ; \theta\right]=W(X, \theta),\right.
$$

where $U\left(x_{i}\right)$ denotes the utility of the $i^{\text {th }}$ household $(i=1, \ldots, n)$ from owning an $x_{i}$ amount of wealth, and where $X$ and $\theta$ are both functions of households' wealth with each representing, respectively, a measure of efficiency and inequity [for in-depth detail, see Inada 1971; Samuelson 1977; Pollak 1979; Johansson 1991; Podder 1993; Mukhopadhaya (2001, 2002, and 2003); and Cowell 2007].

Aside from the dependence of $W$ as described in (1) on the utility $\left(U_{i}\right)$ levels of households, and under the assumption of negatively sloping social indifference curves, it further assumes that social welfare is increasing in each household's utility. This second property enables $W$ to satisfy the (strong) Pareto criterion of social ranking since a rise in the utility of the ith household, ceteris paribus, increases social welfare. ${ }^{7}$ Yet another property is that the strength of any tradeoffs is expected to depend on the extent of inequality, and that social welfare is higher when inequality is lower. This property guarantees that the indifference curves of $W$ are convex to the origin. Hence, the social welfare function $W$ needs to satisfy:

$$
\frac{\partial W}{\partial X}>0 \quad \text { and } \quad \frac{\partial W}{\partial \theta}<0,
$$

which signifies that an increase in efficiency will enhance social welfare while an increase in inequality will diminish social welfare (Mukhopadhaya, 2002). Given that many social welfare functions satisfy (2), Sen (1997) underlined, based on the notion that social marginal utility is inversely related to the rank of the selected economic measure and based on widely-accepted inequality axioms, the advantage of employing a specialized form of the Bergson-Samuelson class of social welfare functions as in the following:

$$
W=\mu_{x}(1-G),
$$

where $\mu_{x}$, in the context of this paper, is mean wealth and $G$ is the Gini index used to measure the level of inequality in the distribution of wealth among farm and non-farm sole proprietor households. The rate of substitution between 'equity' and 'efficiency' at a stationary social welfare level is obtained by equating the total differential of (3) to zero:

$$
\begin{aligned}
d W & =(1-G) d \mu_{x}+\mu_{x} d(1-G)=0 \\
& =(1-G) d \mu_{x}-\mu_{x} d G=0 .
\end{aligned}
$$

After collecting terms, equation (4) produces the slope of an indifference curve of social welfare function $(W)$ in a space that spans both inequality and mean level of $N W:^{8}$

$$
\left.\frac{d \mu_{x}}{d G}\right|_{W}=\frac{\mu_{x}}{1-G} .
$$

\footnotetext{
${ }^{6}$ This part of the paper draws heavily on previous research by Johansson (1991, pp. 22-35), Podder (1993), and Mukhopadhaya (2002). It also follows closely the work of El-Osta and Morehart (2009) where a similar research was undertaken to decompose the welfare of farm operator households in the U.S. by age cohorts using a combined income and annuitized wealth measure of economic well-being.

${ }^{7}$ The strong (weak) Pareto principle argues that world (social states) A is socially preferable to world (social states) B, if at least one person (everyone) ranks $\mathrm{A}$ higher than $\mathrm{B}$ and no one ranks B higher than $\mathrm{A}$.

${ }^{8}$ The steps that are needed in the decomposition of the disparity of wealth and of social welfare by age groups are provided in the appendix.
} 


\section{Results}

Figure 1 presents the 2013 and 2016 medians of net worth of sole proprietor farm and nonfarm households along with the corresponding changes in their levels by the age category of household head. As shown in the top portion of the figure, the overall median wealth of non-farm households between 2013 and 2016 declined by 8.2 percent. In comparison, and in the same timeframe, the median wealth of farm households, as shown in the lower charts, increased by 7.6 percent. While those non-farm households with household head aged 65 years or older exhibited the largest drop in median wealth (about 19\%), those farm households with operators aged 34 years or younger exhibited the largest increase in median wealth $(33 \%)$.

The inequality in the distribution of wealth among sole proprietor households is captured in table 1. While the results show that inequality in the distribution of $N W$, as measured by the Gini index, was much higher for non-farm households than for farm households in both 2013 (i.e., 0.774 vs. 0.515) and 2016 (i.e., 0.807 vs. 0.535), findings further point to an increase in inequality for both farm and non-farm households across these two time periods. ${ }^{9}$ To demonstrate, between 2013 and 2016, the Gini index of $N W$ for non-farm households has increased from 0.774 to 0.807 , which indicates an increase in inequality by 4.3 percent. ${ }^{10}$ Over the same two respective years, the increase in wealth inequality among sole proprietor farm households was much milder as the Gini index exhibited an increase by only $3.9 \%$, although lacking statistical significance, from a value of 0.515 to $0.535 .^{11}$ The fact that the inequality in wealth among non-farm sole proprietor households was much higher than for farm households is explained by the larger shares of wealth captured by those households in the upper 20 percent of the distribution of $N W$; an economic outcome that persisted in each of the age categories considered in both 2013 and 2016 (table 1).

\footnotetext{
${ }^{9}$ Statistical difference between the Gini indices of farm and non-farm household wealth was examined based on estimated $95 \%$ confidence intervals of histograms (measured at the $2.5^{\text {th }}$ percentile and the $97.5^{\text {th }}$ percentile) of these respective indices that were derived from 1,000 bootstrap resamples. The lower and upper confidence limits of these intervals in 2013, respectively, were [0.764; 0.784] and [0.504; 0.526]; and in 2016, these lower and upper confidence limits were [0.799; 0.816] and [0.520;0.549]. Since the confidence intervals were non-overlapping for farm and non-farm households in 2013 and 2016, the differences in Gini indices of farm household wealth for both groups of households and in both years were thus statistically different.

${ }^{10}$ Based on non-overlapping 95\% confidence intervals of the Gini coefficient of wealth in 2013 and 2016, the increase in wealth inequality for non-farm households was statistically significant.

${ }^{11}$ Since the 95\% confidence intervals of the Gini coefficient of wealth in 2013 and 2016 were over-lapping, the increase in wealth inequality among household wealth across these two years was not statistically significant.
} 

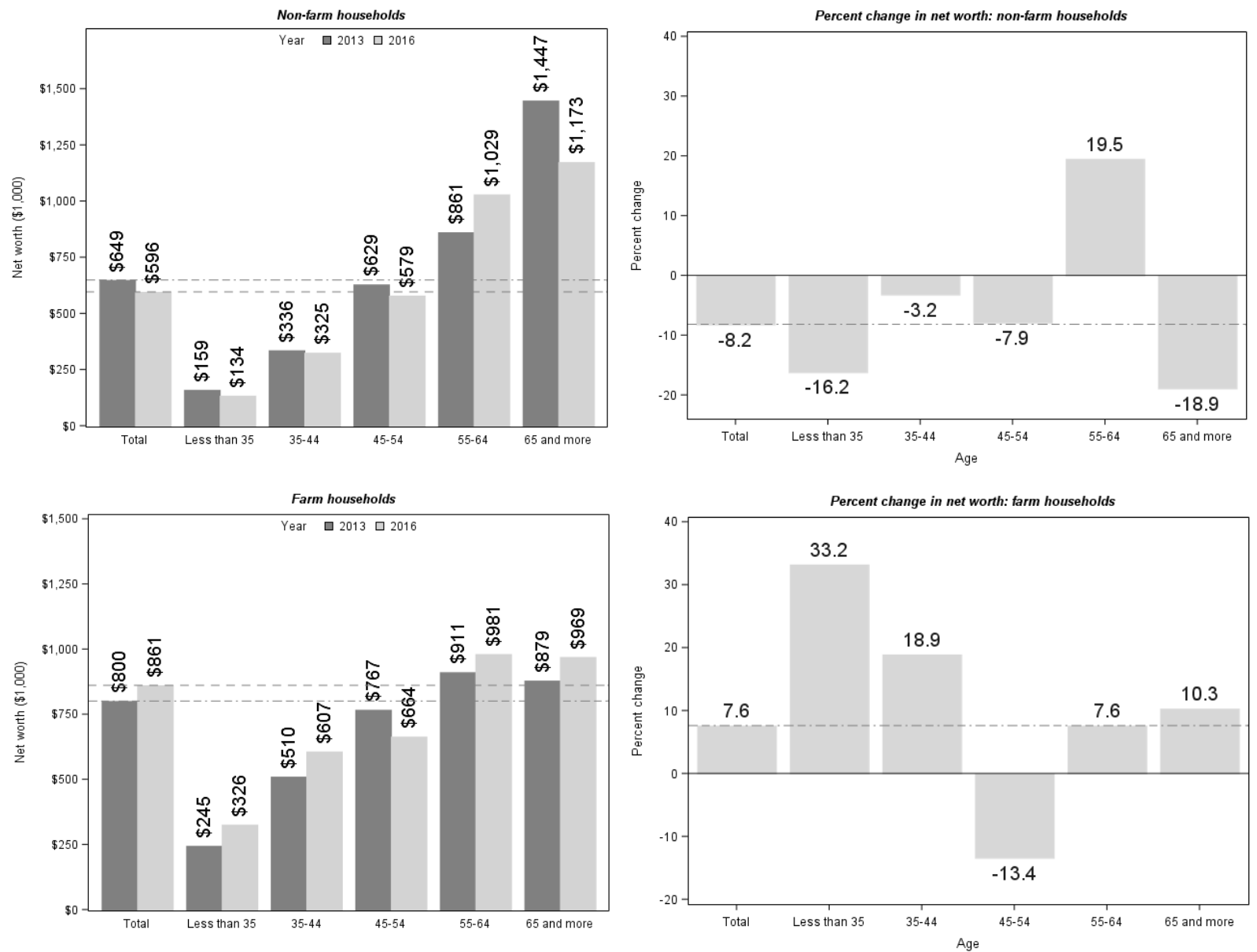

Figure 1. Median and change in median net worth of sole proprietor farm and nonfarm households by operator's age: 2013 and 2016 
Table 1. Wealth inequality among sole proprietor farm and non-farm households by age categories: 2013 and $2016^{1}$

\begin{tabular}{|c|c|c|c|c|c|c|}
\hline \multirow[b]{4}{*}{ Age } & 2013 & & \multicolumn{2}{|l|}{2016} & \multirow{2}{*}{\multicolumn{2}{|c|}{2013}} \\
\hline & \multicolumn{4}{|l|}{ Non-farm } & & \\
\hline & \multicolumn{4}{|c|}{ Proportion of wealth in that age category owned by: } & \multicolumn{2}{|c|}{$\begin{array}{l}\text { Dispersion } \\
\text { measure: }\end{array}$} \\
\hline & $\begin{array}{l}\text { Bottom20 } \\
\%\end{array}$ & Top $20 \%$ & Bottom 20\% & Top $20 \%$ & \multicolumn{2}{|c|}{ Gini coefficient } \\
\hline \multirow[t]{2}{*}{ Less than 35} & -0.19 & 84.29 & -0.12 & 78.70 & 0.813 & 0.744 \\
\hline & $(0.19)$ & $(2.47)$ & $(0.25)$ & $(2.84)$ & $(0.019)$ & $(0.030)$ \\
\hline \multirow[t]{2}{*}{$35-44$} & 0.24 & 85.36 & 0.38 & 83.69 & 0.806 & 0.805 \\
\hline & $(0.04)$ & $(1.09)$ & $(0.15)$ & $(1.64)$ & $(0.010)$ & $(0.018)$ \\
\hline \multirow[t]{2}{*}{$45-54$} & 0.34 & 80.47 & 0.43 & 82.30 & 0.781 & 0.791 \\
\hline & $(0.08)$ & $(1.34)$ & $(0.07)$ & $(1.20)$ & $(0.011)$ & $(.010)$ \\
\hline \multirow[t]{2}{*}{$55-64$} & 0.47 & 76.53 & 0.68 & 81.11 & 0.730 & 0.770 \\
\hline & $(0.10)$ & $(1.11)$ & $(0.07)$ & $(0.95)$ & $(0.010)$ & $(0.009)$ \\
\hline \multirow[t]{2}{*}{65 or older } & 0.93 & 75.46 & 0.33 & 81.74 & 0.718 & 0.793 \\
\hline & $(0.10)$ & $(1.38)$ & $(0.04)$ & $(1.25)$ & $(0.013)$ & $(0.010)$ \\
\hline \multirow{2}{*}{ All households } & 0.26 & 80.78 & 0.36 & 84.10 & 0.774 & 0.807 \\
\hline & $(0.03)$ & $(0.60)$ & $(0.03)$ & $(0.53)$ & $(0.005)$ & $(0.004)$ \\
\hline Sample size & & & & & 4,795 & 4,850 \\
\hline \multirow[t]{2}{*}{ Expanded sample } & & & & & 7.9 mil. & $8.3 \mathrm{mil}$. \\
\hline & Farm & & & & & \\
\hline \multirow[t]{2}{*}{ Less than 35} & 1.92 & 66.96 & 1.52 & 64.93 & 0.626 & 0.617 \\
\hline & $(0.57)$ & $(2.59)$ & $(0.76)$ & (4.37) & $(0.025)$ & $(0.046)$ \\
\hline \multirow[t]{2}{*}{$35-44$} & 3.03 & 56.32 & 2.26 & 64.27 & 0.521 & 0.602 \\
\hline & $(0.46)$ & $(1.67)$ & $(0.59)$ & $(3.19)$ & $(0 . .017)$ & $(0.033)$ \\
\hline \multirow[t]{2}{*}{$45-54$} & 2.98 & 57.62 & 2.72 & 57.65 & 0.531 & 0.537 \\
\hline & $(0.24)$ & (1.17) & $(0.34)$ & (1.59) & $(0.013)$ & $(0.016)$ \\
\hline \multirow[t]{2}{*}{$55-64$} & 3.78 & 54.50 & 4.21 & 53.75 & 0.495 & 0.482 \\
\hline & $(0.20)$ & $(0.89)$ & $(0.26)$ & $(1.00)$ & $(0.009)$ & $(0.011)$ \\
\hline \multirow[t]{2}{*}{65 or older } & 4.01 & 54.62 & 3.34 & 57.95 & 0.496 & 0.533 \\
\hline & $(0.21)$ & $(0.93)$ & $(0.21)$ & (1.33) & $(0.010)$ & $(0.013)$ \\
\hline \multirow[t]{2}{*}{ All households } & 3.31 & 55.92 & 3.04 & 57.79 & 0.515 & 0.535 \\
\hline & $(0.12)$ & $(0.54)$ & $(.144)$ & $(0.76)$ & $(0.006)$ & $(0.008)$ \\
\hline Sample size & & & & & 12,965 & 11,642 \\
\hline Expanded sample & & & & & 1.9 mil. & $1.8 \mathrm{mil}$. \\
\hline
\end{tabular}

${ }^{1}$ At 2016 price levels. Standard deviations for all estimates are in parentheses and are computed based on the delete-one Jackknife variance estimation method. Similar estimate values of standard deviations were obtained based on bootstrapping estimation method with 1,000 replicate samples.

Table 2 presents the 2013 and 2016 summary statistics necessary for the allotment of social welfare by the age of the household head. For both farm and non-farm sole proprietor households, results indicate that the mean $N W$ and the concentration coefficient in both years are highest when head of household is aged 65 years or older. The high average value of $N W$ and the high concentration coefficients amongst sole proprietor households with older heads indicate, in comparison to the population at large of farm and non-farm households, that a large proportion of households in this age group are in the upper wealth brackets, a finding which is consistent with the evidence from both the SCF and ARMS datasets. For example, while under 20 percent of non-farm sole proprietor households in both 2013 and 2016 had household heads aged 65 or older, about 30 percent of all households with heads in this age group were located in the highest quantile of the wealth distribution. Similarly, while about one-third of all farm sole proprietor households in both 2013 and 2016 had household heads aged 65 or older, about 40 percent of households with heads in this age group were located in the highest quantile of the wealth distribution. Table 2 also demonstrates a higher share of accumulated wealth by older farm households than by their non-farm older counterparts. Specifically, while those non-farm households aged 65 or older captured in 2013 and 2016 about $29 \%$ and 32\% of the wealth, respectively, those farm households in the same age group captured a corresponding $37 \%$ and $41 \%$ percent of the wealth. 
Table 2. Averages and shares of wealth, shares of population, and concentration coefficients for farm and non-farm households by age categories: 2013 and $2016^{1}$

\begin{tabular}{|c|c|c|c|c|c|c|c|c|}
\hline $\begin{array}{l}\text { Age } \\
\text { categories }\end{array}$ & \multicolumn{2}{|c|}{$N W\left(\bar{x}_{k}\right)$} & \multicolumn{2}{|c|}{$\left[\frac{N_{k}}{N}(\%)\right]$} & \multicolumn{2}{|c|}{$\left[\frac{X^{k}}{X^{T}}(\%)\right]$} & \multicolumn{2}{|c|}{$\begin{array}{c}\text { coefficients } \\
\left(C_{k}\right) \\
\end{array}$} \\
\hline \multicolumn{9}{|c|}{ Non-farm households } \\
\hline Younger than 35 & $\begin{array}{r}869,834 \\
(112,231)\end{array}$ & $\begin{array}{l}355,329 \\
(51,543)\end{array}$ & $\begin{array}{r}9.35 \\
(0.77)\end{array}$ & $\begin{array}{r}7.76 \\
(0.68)\end{array}$ & $\begin{array}{r}2.79 \\
(0.36)\end{array}$ & $\begin{array}{r}0.84 \\
(0.14)\end{array}$ & $\begin{array}{r}0.576 \\
(0.004)\end{array}$ & $\begin{array}{r}0.241 \\
(0.073)\end{array}$ \\
\hline 35 to 44 & $\begin{array}{l}1,886,518 \\
(129,593)\end{array}$ & $\begin{array}{l}1,366,150 \\
(133,167)\end{array}$ & $\begin{array}{l}23.28 \\
(0.28)\end{array}$ & $\begin{array}{r}16.35 \\
(0.79)\end{array}$ & $\begin{array}{l}15.07 \\
(0.98)\end{array}$ & $\begin{array}{r}6.82 \\
(0.62)\end{array}$ & $\begin{array}{r}0.722 \\
(0.016)\end{array}$ & $\begin{array}{r}0.660 \\
(0.030)\end{array}$ \\
\hline 45 to 54 & $\begin{array}{l}2,740,198 \\
(147,825)\end{array}$ & $\begin{array}{l}3,205,021 \\
(192,643)\end{array}$ & $\begin{array}{l}22.64 \\
(0.95)\end{array}$ & $\begin{array}{l}27.71 \\
(1.02)\end{array}$ & $\begin{array}{l}21.29 \\
(1.03)\end{array}$ & $\begin{array}{l}27.12 \\
(1.29)\end{array}$ & $\begin{array}{r}0.760 \\
(0.012)\end{array}$ & $\begin{array}{r}0.799 \\
(0.010)\end{array}$ \\
\hline 55 to 64 & $\begin{array}{l}3,265,368 \\
(160,939)\end{array}$ & $\begin{array}{l}3,914,556 \\
(189,528)\end{array}$ & $\begin{array}{l}28.32 \\
(1.01)\end{array}$ & $\begin{array}{r}28.07 \\
(0.99)\end{array}$ & $\begin{array}{l}31.73 \\
(1.34)\end{array}$ & $\begin{array}{l}33.54 \\
(1.28)\end{array}$ & $\begin{array}{r}0.776 \\
(0.009)\end{array}$ & $\begin{array}{r}0.812 \\
(0.008)\end{array}$ \\
\hline 65 or older & $\begin{array}{l}5,173,759 \\
(292,333)\end{array}$ & $\begin{array}{l}5,160,598 \\
(272,363)\end{array}$ & $\begin{array}{l}16.41 \\
(0.85)\end{array}$ & $\begin{array}{r}20.11 \\
(0.92)\end{array}$ & $\begin{array}{l}29.12 \\
(1.33)\end{array}$ & $\begin{array}{l}31.68 \\
(1.23)\end{array}$ & $\begin{array}{r}0.829 \\
(0.009)\end{array}$ & $\begin{array}{r}0.856 \\
(0.007)\end{array}$ \\
\hline Total & $\begin{array}{r}2,914,562 \\
(79,523)\end{array}$ & $\begin{array}{r}3,275,582 \\
(90,964)\end{array}$ & $\begin{array}{r}100.00 \\
-\end{array}$ & $\begin{array}{r}100.00 \\
-\end{array}$ & $\begin{array}{r}100.00 \\
--\end{array}$ & $\begin{array}{r}100.00 \\
--\end{array}$ & $\begin{array}{r}0.774^{2} \\
(0.005)\end{array}$ & $\begin{array}{c}0.807^{2} \\
(0.004)\end{array}$ \\
\hline Farm households & & & & & & & & \\
\hline Younger than 35 & $\begin{array}{l}559,733 \\
(60,220)\end{array}$ & $\begin{array}{l}592,621 \\
(74,068)\end{array}$ & $\begin{array}{r}4.06 \\
(0.35)\end{array}$ & $\begin{array}{r}4.38 \\
(0.44)\end{array}$ & $\begin{array}{r}1.82 \\
(0.19)\end{array}$ & $\begin{array}{r}1.84 \\
(0.25)\end{array}$ & $\begin{array}{r}0.237 \\
(0.070)\end{array}$ & $\begin{array}{r}0.178 \\
(0.099)\end{array}$ \\
\hline 35 to 44 & $\begin{array}{l}837,108 \\
(40,071)\end{array}$ & $\begin{array}{l}1,080,538 \\
(105,992)\end{array}$ & $\begin{array}{r}8.73 \\
(0.52)\end{array}$ & $\begin{array}{r}8.58 \\
(0.63)\end{array}$ & $\begin{array}{r}5.86 \\
(0.38)\end{array}$ & $\begin{array}{r}6.56 \\
(0.62)\end{array}$ & $\begin{array}{r}0.315 \\
(0.032)\end{array}$ & $\begin{array}{r}0.434 \\
(0.055)\end{array}$ \\
\hline 45 to 54 & $\begin{array}{r}1,219,374 \\
(47,075)\end{array}$ & $\begin{array}{r}1,138,964 \\
(61,971)\end{array}$ & $\begin{array}{l}17.42 \\
(0.62)\end{array}$ & $\begin{array}{l}16.48 \\
(0.87)\end{array}$ & $\begin{array}{l}17.04 \\
(0.73)\end{array}$ & $\begin{array}{l}13.27 \\
(0.82)\end{array}$ & $\begin{array}{r}0.509 \\
(0.019)\end{array}$ & $\begin{array}{r}0.443 \\
(0.027)\end{array}$ \\
\hline 55 to 64 & $\begin{array}{r}1,337,164 \\
(35,334)\end{array}$ & $\begin{array}{r}1,505,104 \\
(42,078)\end{array}$ & $\begin{array}{l}35.73 \\
(0.86)\end{array}$ & $\begin{array}{l}35.09 \\
(1.07)\end{array}$ & $\begin{array}{l}38.34 \\
(1.02)\end{array}$ & $\begin{array}{l}37.36 \\
(1.26)\end{array}$ & $\begin{array}{r}0.537 \\
(0.013)\end{array}$ & $\begin{array}{r}0.536 \\
(0.014)\end{array}$ \\
\hline 65 or older & $\begin{array}{r}1,350,642 \\
(37,704)\end{array}$ & $\begin{array}{r}1,633,169 \\
(74,326)\end{array}$ & $\begin{array}{l}34.06 \\
(0.86)\end{array}$ & $\begin{array}{l}35.47 \\
(1.11)\end{array}$ & $\begin{array}{l}36.92 \\
(1.02)\end{array}$ & $\begin{array}{r}40.97 \\
(1.50)\end{array}$ & $\begin{array}{r}0.540 \\
(0.012)\end{array}$ & $\begin{array}{r}0.595 \\
(0.017)\end{array}$ \\
\hline Total & $\begin{array}{r}1,246,017 \\
(20,363)\end{array}$ & $\begin{array}{r}1,413,779 \\
(33,575) \\
\end{array}$ & 100.00 & 100.00 & 100.00 & 100.00 & $\begin{array}{c}0.515^{2} \\
(0.006)\end{array}$ & $\begin{array}{r}0.535^{2} \\
(0.008)\end{array}$ \\
\hline
\end{tabular}

${ }^{1}$ At 2016 price levels. Standard deviations for all estimates are in parentheses and are computed based on the bootstrapping estimation method with 1,000 replicate samples.

${ }^{2}$ These are the Gini coefficients of the wealth measure for the total population.

Findings of the welfare decomposition based on five age groups are presented in table 3. For non-farm sole proprietor households, total social welfare has decreased by 4.1 percent, from $\$ 657,986$ in 2013 to $\$ 631,011$ in $2016 .{ }^{12}$ In contrast, findings point to a statistically significant rise by 8.8 percent in total social welfare for farm sole proprietor households, from $\$ 604,553$ in 2013 to $\$ 658,029$ in $2016 .{ }^{13}$ To the extent that the change in wealth inequality between 2013 and 2016 as measured by the Gini index $(G)$ is found insignificant, which in turn alludes to an insignificant change in equity as indicated in equation 9 in the appendix, the increase in total social welfare among sole proprietor farm households is explained by the rise in efficiency in the distribution of wealth as shown by the rise in average wealth.

${ }^{12}$ Based on overlapping confidence intervals of the total social welfare in 2013 and 2016, the decrease in social welfare for non-farm households was not statistically significant.

${ }^{13}$ The statistical significance of the difference in total social welfare among farm households between 2013 and 2016 is based on non-overlapping confidence intervals. 
Table 3. Decomposition of welfare for farm and non-farm households by age categories: 2013 and $2016^{1}$

\begin{tabular}{|c|c|c|c|c|c|c|}
\hline \multirow[t]{2}{*}{ Age categories } & \multicolumn{2}{|c|}{$\begin{array}{l}\text { Absolute share } \\
\text { of total welfare } \\
\left.\text { [ } \phi_{k}(2016 \text { dollars })\right]\end{array}$} & \multicolumn{2}{|c|}{$\begin{array}{l}\text { Relative share } \\
\text { of total welfare } \\
\left(\varpi_{k}\right)\end{array}$} & \multicolumn{2}{|c|}{$\begin{array}{l}\text { Marginal effect } \\
\left(\xi_{k}\right)\end{array}$} \\
\hline & 2013 & 2016 & 2013 & 2016 & 2013 & 2016 \\
\hline & \multicolumn{6}{|c|}{ Non-farm households } \\
\hline Younger than 35 & $\begin{array}{l}34,478 \\
(3,664)\end{array}$ & $\begin{array}{l}20,927 \\
(2,572)\end{array}$ & $\begin{array}{l}0.052 \\
(0.005)\end{array}$ & $\begin{array}{l}0.033 \\
(0.004)\end{array}$ & $\begin{array}{l}1.877 \\
(0.195)\end{array}$ & $\begin{array}{l}3.938 \\
0.380))\end{array}$ \\
\hline 35 to 44 & $\begin{array}{l}121,881 \\
6,990)\end{array}$ & $\begin{array}{l}76,014 \\
(4,308)\end{array}$ & $\begin{array}{l}0.185 \\
(0.009)\end{array}$ & $\begin{array}{l}0.120 \\
(0.007)\end{array}$ & $\begin{array}{l}1.229 \\
(0.066)\end{array}$ & $\begin{array}{l}1.767 \\
(0.150)\end{array}$ \\
\hline 45 to 54 & $\begin{array}{l}149,044 \\
(8,572)\end{array}$ & $\begin{array}{l}178,167 \\
(9,546)\end{array}$ & $\begin{array}{l}0.227 \\
(0.010)\end{array}$ & $\begin{array}{l}0.282 \\
(0.011)\end{array}$ & $\begin{array}{l}1.064 \\
(0.043)\end{array}$ & $\begin{array}{l}1.041 \\
(0.047)\end{array}$ \\
\hline 55 to 64 & $\begin{array}{l}207,316 \\
(11,282)\end{array}$ & $\begin{array}{l}206,038 \\
(10,349)\end{array}$ & $\begin{array}{l}0.315 \\
(0.012)\end{array}$ & $\begin{array}{l}0.327 \\
(0.011)\end{array}$ & $\begin{array}{l}0.993 \\
(0.034)\end{array}$ & $\begin{array}{l}0.973 \\
(0.035)\end{array}$ \\
\hline 65 or older & $\begin{array}{l}145,267 \\
(9,474)\end{array}$ & $\begin{array}{l}149,865 \\
(8,976)\end{array}$ & $\begin{array}{l}0.221 \\
(0.010)\end{array}$ & $\begin{array}{l}0.237 \\
(0.011)\end{array}$ & $\begin{array}{l}0.758 \\
(0.032)\end{array}$ & $\begin{array}{l}0.750 \\
(0.031)\end{array}$ \\
\hline \multirow[t]{2}{*}{ Total } & $\begin{array}{l}657,986 \\
(24,856)\end{array}$ & $\begin{array}{l}631,011 \\
(21,958)\end{array}$ & 1.000 & 1.000 & 1.000 & 1.000 \\
\hline & \multicolumn{6}{|c|}{ Farm households } \\
\hline Younger than 35 & $\begin{array}{l}17,335 \\
(1,265)\end{array}$ & $\begin{array}{l}21,335 \\
(2,312)\end{array}$ & $\begin{array}{l}0.029 \\
(0.002)\end{array}$ & $\begin{array}{l}0.032 \\
(0.004)\end{array}$ & $\begin{array}{l}1.572 \\
(0.146)\end{array}$ & $\begin{array}{l}1.765 \\
(0.214)\end{array}$ \\
\hline 35 to 44 & $\begin{array}{l}50,070 \\
(3,353)\end{array}$ & $\begin{array}{l}52,532 \\
(3,929)\end{array}$ & $\begin{array}{l}0.083 \\
(0.006)\end{array}$ & $\begin{array}{l}0.080 \\
(0.006)\end{array}$ & $\begin{array}{l}1.412 \\
(0.065)\end{array}$ & $\begin{array}{l}1.217 \\
(0.115)\end{array}$ \\
\hline 45 to 54 & $\begin{array}{l}104,180 \\
(4,290)\end{array}$ & $\begin{array}{l}104,564 \\
(5,864)\end{array}$ & $\begin{array}{l}0.172 \\
(0.007)\end{array}$ & $\begin{array}{l}0.159 \\
(0.009)\end{array}$ & $\begin{array}{l}1.011 \\
(0.038)\end{array}$ & $\begin{array}{l}1.197 \\
(0.061)\end{array}$ \\
\hline 55 to 64 & $\begin{array}{l}221,160 \\
(7,177)\end{array}$ & $\begin{array}{l}244,869 \\
(9,830)\end{array}$ & $\begin{array}{l}0.366 \\
(0.010)\end{array}$ & $\begin{array}{l}0.372 \\
(0.012)\end{array}$ & $\begin{array}{l}0.954 \\
(0.023)\end{array}$ & $\begin{array}{l}0.996 \\
(0.030)\end{array}$ \\
\hline 65 or older & $\begin{array}{l}211,808 \\
(6,775)\end{array}$ & $\begin{array}{l}234,727 \\
(9,471)\end{array}$ & $\begin{array}{l}0.350 \\
(0.009)\end{array}$ & $\begin{array}{l}0.357 \\
(0.012)\end{array}$ & $\begin{array}{l}0.949 \\
(0.023)\end{array}$ & $\begin{array}{l}0.871 \\
(0.029)\end{array}$ \\
\hline Total & $\begin{array}{l}604,553 \\
(9,892)\end{array}$ & $\begin{array}{l}658,029 \\
(13,533)\end{array}$ & 1.000 & 1.000 & 1.000 & 1.000 \\
\hline
\end{tabular}

${ }^{1} \phi_{k}=\frac{N_{k}}{N} \bar{x}_{k}\left(1-C_{k}\right) ; \varpi=\frac{\phi_{k}}{\bar{x}(1-G)} ; \xi_{k}=\frac{1-C_{k}}{1-G}$.

Note: Standard deviations for all estimates are in parentheses and are computed based on the bootstrapping estimation method with 1,000 replicate samples.

For those farm and non-farm sole proprietor households in 2013 and 2016 where the age of the head was in the '55 to 64' year old category, and as evident in table 3, both absolute and relative shares of total social welfare are highest in comparison to when the age of the head falls in the other age categories. This finding concerning the high level of social welfare for both types of households in the 55- to 64-year old age group is explained by their strong financial position relative to households in the other age groups. Specifically, and as evident in table 2, non-farm sole proprietor households in the ' 55 to 64 ' year old group captured nearly 30 percent of both the total population of non-farm households and the total amount of $N W$ in both 2013 and 2016. Likewise, farm sole proprietor households in this age category accounted for over 35 percent of both the total population of farm households and the total amount of wealth in both years.

The efficacy of a dollar increase in wealth $(N W)$ for any of the five age groups is asserted, as described in equation 11 in the appendix, by values of $\xi_{k}$ larger than unity. Results in table 3 show that such a rise in $N W$ of farm and non-farm households whose head is younger than 55 in both 2013 and 2016, will generate more social welfare than the effect of such an increase being expended over the whole society. Of these three age groups, the group where the age of the head is younger than 35 years old has the highest level of $\xi_{k}$. As shown in figure 2, the median income of the group of sole proprietor farm households with farmers aged 34 years or younger is lower than the median incomes of the other groups of households; except for the group of households with farmers aged 65 years or older. Accordingly, any improvement in the U.S. labor market conditions that would result in an increased access to higher paying jobs, particularly among these sole proprietors aged 34 years or younger, would also likely generate an improvement in the economic well-being 
of their households through the potential of income-based wealth creation, and consequently, to a higher level of social welfare.
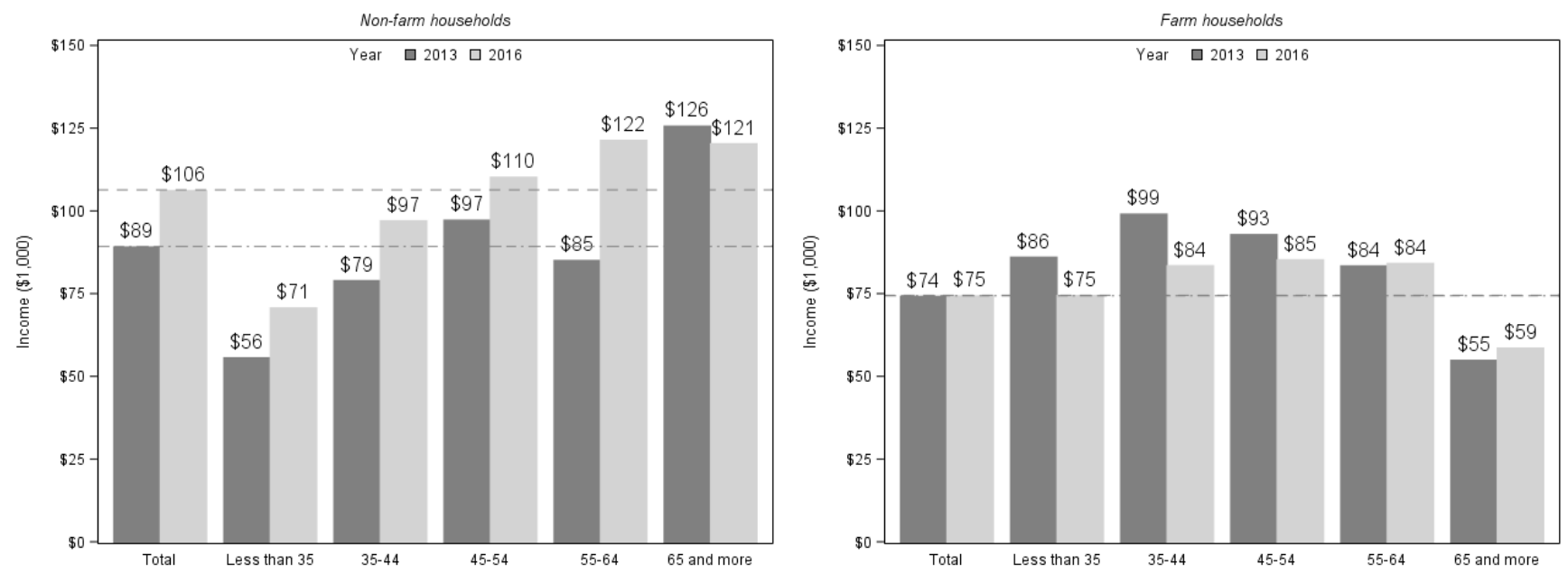

Figure 2. Median income of sole proprietor farm and nonfarm households by operator's age: 2013 and 2016

\section{Summary and Conclusions}

This paper has used data from the Agricultural Resource Management Survey and the Survey of Consumer Finances to examine, respectively, the distribution of wealth among farm and non-farm sole proprietor households in 2013 and 2016. In addition, it has assessed and partitioned total social welfare of these two groups of households based on five age cohorts.

Findings, based on Gini coefficient analysis of the distributions of the wealth measure $(N W)$ for both farm and non-farm sole proprietor households, revealed an increasing inequality for both types of households between 2013 and 2016, although the increase was statistically significant only for non-farm households. In addition, findings have pointed to a much pronounced level of dispersion in these distributions for non-farm households in comparison to farm households.

Using Podder's method of welfare decomposition, findings alluded to a statistically insignificant slight decrease in total social welfare among non-farm sole proprietor household over the 2013 and 2016 time period. In contrast, and over the same time period, findings pointed to a statistically significant increase in total social welfare for farm sole proprietor households; an increase that was attributable to the rise in efficiency in the distribution of wealth as a result to the upswing in average wealth. Results further shown the significance of the ' 55 to 64' age group in terms of its contribution towards the total social welfare of both farm and non-farm households. A marginal one dollar increase in the total wealth of those farm or non-farm households whose head is younger than 35 is found to yield the maximum increase in social welfare than the effect of the same dollar increase being spread over the whole society. This finding is in accord with the result by El-Osta (2009) where an economic indicator of well-being based on a combined income and annuitized wealth measure was used, instead of just wealth, in the partitioning of total social welfare among farm households.

Considering the finding of a high impact on total social welfare resulting from a marginal increase in wealth among households of the youngest farm age cohort, any improvement in the farm incomes of beginning farmers who tend to be younger than established farmers, which in turn would allow for wealth formation through increased savings and investment, would likely have the largest benefit. ${ }^{14}$ To the extent that beginning family farms tend to be smaller and more dependent on income from off-farm sources than established family farms, a healthy U.S. economic outlook that

${ }^{14}$ Data from the 2016 ARMS show that the average age of beginning sole proprietor farmers (i.e., those farmers with less than 10 years of farming experience) was at 49 years compared to 61 years for the established sole proprietor farmers (i.e., those who are not beginning farmers). Also, while about $19 \%$ of all beginning sole proprietor farmers in 2016 were aged 34 years or younger, $1 \%$ of established sole proprietor farmers were in this young age group. 
results in an enhanced access to off-farm labor markets and at improved off-farm wages would also likely to aid in wealth creation and in improved social welfare for these households. ${ }^{15}$

\section{About the Author}

Hisham El-Osta is a former agricultural economist with the Economic Research Service, United States Department of Agriculture. The findings and conclusions in this article are those of the author and should not be construed to represent any official USDA or U.S. Government determination or policy.

\section{Acknowledgements}

The author is grateful for the insightful critical comments provided by the anonymous reviewers of this journal.

\section{References}

Ahearn, M. C., \& El-Osta, H. S. (1991). Farm Wealth: Its Distribution and Comparison to the Wealth of U. S. Households. In Agricultural Income and Finance: Situation and Outlook Report (pp. 21-23). Pub. \# Afo-41, USDA/Economic Research Service, Washington D.C.

Ando, A., \& Modigliani, F. (1963). The "Life Cycle" Hypothesis of Saving: Aggregate Implications and Tests. The American Economic Review, 53(1), 55-84.

Atkinson, A. B. (1970). On the Measurement of Inequality. Journal of Economic Theory, 2(3), 244-263. https://doi.org/10.1016/0022-0531(70)90039-6

Atkinson, A. B. (1971). The Distribution of Wealth and the Individual Life-Cycle. Oxford Economic Papers, 23(2), 239-254. https://doi.org/10.1093/oxfordjournals.oep.a041192

Balestra, C., \& Tonkin, R. (2018). Inequalities in Household Wealth across OECD Countries: Evidence from the OECD Wealth Distribution Database. Organisation for Economic Cooperation and Development (OECD). Working Paper No. 88 .

Batte, M. T., Jones, E., \& Schnitkey, G. D. (1990). Computer Use by Ohio Commercial Farmers. American Journal of Agricultural Economics, 72(4), 935-945. https://doi.org/10.2307/1242625

Boehlje, M. (1973). The Entry-Growth-Exit Processes in Agriculture. Southern Journal of Agricultural Economics, 5(1), 23-36. https://doi.org/10.1017/S0081305200010773

Boehlje, M. (1992). Alternative Models of Structural Change in Agriculture and Related Industries. Agribusiness, 8(3), 219-231.

Bricker, J., Henriques, A., \& Moore, K. (2017). Updates to the Sampling of Wealthy Families in the Survey of Consumer Finances. Finance and Economics Discussion Series 2017-114. Washington: Board of Governors of the Federal Reserve System. https://doi.org/10.17016/FEDS.2017.114

Browning, B., \& Lusardi, A. (1996). Household Saving: Micro Theories and Micro Facts. Journal of Economic Literature, 34(4), 1797-1855.

Cagetti, M. (2003). Wealth Accumulation over the Life-Cycle and Precautionary Savings. Journal of Business and Economic Statistics, 21(3), 339-353. https://doi.org/10.1198/073500103288619007

Cagetti, M., \& De Nardi, M. (2008). Wealth Inequality: Data and Models. Macroeconomic Dynamics, 12(S2), 285-313. https://doi.org/10.1017/S1365100507070150

Cowell, F. A. (2007). Measurement of Inequality. In Atkinson, A.B. \& Bourguignon, F., eds., Handbook of Income Distribution (Vol. 1). Oxford, UK: Elsevier North Holland Publishing.

Dasgupta, P., Sen, A., \& Starrett, D. (1973). Notes on the Measurement of Inequality. Journal of Economic Theory, 6(2), 180-187. https://doi.org/10.1016/0022-0531(73)90033-1

El-Osta, H., \& Morehart, M. (2002). The Dynamics of Wealth Concentration Among Farm Operator Households. Agricultural and Resource Economics Review, 31(1), 84-96. https://doi.org/10.1017/S1068280500003506

El-Osta, H., \& Morehart, M. (2008). Determinants of Poverty among U.S. Farm Households. Journal of Agricultural and Applied Economics, 40(1), 1-20. https://doi.org/10.1017/S1074070800027942

${ }^{15}$ Data from the 2016 ARMS show that the average farm size of beginning family farms was 169 acres, which was dramatically smaller than the average size of 337 acres for established family farms. Similarly, the income from off-farm wages and salaries and from an off-farm business for beginning farms in 2016 comprised nearly $73 \%$ of total household income; compared to 55\% for established farms. Furthermore, a study by Sumner (1982) showed that a 10\% increase in off-farm wage rate is associated with an $11 \%$ increase in off-farm work hours by farm operators. 
El-Osta, H., \& Morehart, M. (2009). Welfare Decomposition in the Context of the Life Cycle of Farm Operators: What Does a National Survey Reveal? Agricultural and Resource Economics Review, 38(2), 125-141. https://doi.org/10.1017/S1068280500003154

Findeis, J., \& Reddy, V. (1987). Decomposition of Income Distribution among Farm Families. Northeastern Journal of Agricultural Economics, 16(2), 165-173. https://doi.org/10.1017/S0899367X00001495

Franco, M. (1988). The Role of Intergenerational Transfers and Life Cycle Saving in the Accumulation of Wealth. The Journal of Economic Perspectives, 2(2), 15-40. https://doi.org/10.1257/jep.2.2.15

Gale, H. F. J. (1994). Longitudinal Analysis of Farm Size Over the Farmer's Life Cycle. Review of Agricultural Economics, 16(1), 113-123. https://doi.org/10.2307/1349526

Gale, H. F. J. (2003). Age-Specific Patterns of Exit and Entry in U.S. Farming, 1978-1997. Review of Agricultural Economics, 25(1), 168-186.

Gale, W. G., \& Scholz, J. K. (1994). Intergenerational Transfers and the Accumulation of Wealth. Journal of Economic Perspectives, 8(4), 145-160. https://doi.org/10.1257/jep.8.4.145

Giorgi, G. M. (2011). The Gini Inequality Index Decomposition, an Evolutionary Study. In The Measurement of Individual Well-Being and Group Inequality: Essay in Memory of Z.M. Berrebi. London: Routledge: $185-218$.

Gottschalk, P. (1993). Changes in Inequality of Family Income in Seven Industrialized Countries. The American Economic Review, Papers and Proceedings of the Hundred and Fifth Annual Meeting of the American Economic Association, 83(2), 136-142.

Haden, K. L., \& Johnson, L. A. (1989). Factors Which Contribute to the Financial Performance of Selected Tennessee Dairies. Southern Journal of Agricultural Economics, 21(1), 105-112. https://doi.org/10.1017/S0081305200000960

Hill, B. (2000). Farm Incomes, Wealth, and Agricultural Policy. Third edition, Ashgate Publishing Ltd., Hants, England.

Huggett, M. (1996). Wealth Distribution in Life-Cycle Economies. Journal of Monetary Economics, 38(3), $469-494$. https://doi.org/10.1016/S0304-3932(96)01291-3

Inada, K. I. (1971). Social Welfare Function and Social Indifference Surfaces. Econometrica, $39(3), 599-623$. https://doi.org/10.2307/1913269

Johansson, P. O. (1991). An Introduction to Modern Welfare Economics London: Cambridge University Press. https://doi.org/10.1017/CBO9780511582417

Keister, L., \& Moller, S. (2000). Wealth Inequality in the United States. Annual Review of Sociology, 16(26), 63-81. https://doi.org/10.1146/annurev.soc.26.1.63

Lerman, R. J., \& Yitzhaki, S. (1985). Income Inequality Effects by Income Source: A New Approach and Applications to the United States. Review of Economics and Statistics, 67(1), 151-156. https://doi.org/10.2307/1928447

Lerman, R. J., \& Yitzhaki, S. (1989). Improving the Accuracy of Estimates of Gini Coefficients. Journal of Econometrics, 42(1), 43-47.

Lindamood, S., Hanna, S. D., \& Bi, L. (2007). Using the Survey of Consumer Finances: Methodological Considerations and Issues. Journal of Consumer Affairs, 41(2), 195-214. https://doi.org/10.1111/j.1745-6606.2007.00075.x

Michael, B. (1992). Alternative Models of Structural Change in Agriculture and Related Industries. Agribusiness, 8(3), 219-231. https://doi.org/10.1002/1520-6297(199205)8:3<219::AID-AGR2720080303>3.0.CO;2-T

Mishra, A. K., \& Chang, H. (2009). Factors Affecting Precautionary Savings of Self-Employed Farm Households. Agricultural Finance Review, 69(3), 300-313. https://doi.org/10.1108/00021460911002680

Mishra, A. K., El-Osta, H. S., Morehart, M. J., Johnson, J. D., \& Hopkins, J. W. (2002). "Income, Wealth, and Well-Being of Farm Operator Households.” Agricultural Economics Report \# 812, Economic Research Service, U.S. Department of Agriculture, Washington, D.C.

Modigliani, F. (1986). Life-Cycle, Individual Thrift, and the Wealth of Nations. American Economic Review, 76(3), 297-313.

Modigliani, F. (1988). The Role of Intergenerational Transfers and Life Cycle Saving in the Accumulation of Wealth. The Journal of Economic Perspectives, 2(2), 15-40.

Mookherjee, D., \& Shorrocks, A. (1982). A Decomposition Analysis of the Trend in UK Income Inequality. Economic Journal, 92(368), 886-902. https://doi.org/10.2307/2232673

Mukhopadhaya, P. (2001). Efficiency Criteria and the Sen-type Social Welfare Function. Working Paper No. 0114, 
National University of Singapore. Retrieved from http://www.fas.nus.edu.sg/ecs/pub/wp/wp0114.pdf

Mukhopadhaya, P. (2002). The Trend of Welfare Disparity among Subgroups of Population in Australia 1983-1984 1993-1994. Applied Economics, 34(4), 1733-1741.

Mukhopadhaya, P. (2003). The Ordinal and Cardinal Judgment of Social Welfare Changes in Singapore, 1982-99. The Developing Economies, 41(1), 65-87.

Organization for Economic Co-operation and Development (OECD). (1998). Agriculture in a Changing World: Which Policies for Tomorrow? Press Communique, Meeting of the OECD Committee for Agriculture at Ministerial Level, SG/COM/NEWS/ (98)22, 5-6 March, 1998, Paris: OECD.

Podder, N. (1993). A New Decomposition of the Gini Coefficient among Groups and its Interpretations with Applications to Australia. Sankhya: The Indian Journal of Statistics, Series B (1960-2002), 55(2), 262-271. Retrieved from https://www.jstor.org/stable/25052790?seq=1\#page_scan_tab_contents

Pollak, R. A. (1979). Bergson-Samuelson Social Welfare Functions and the Theory of Social Choice. The Quarterly Journal of Economics, 93(1), 73-90. https://doi.org/10.2307/1882599

Prager, D., \& Lyons, G. (2018). Income and Wealth in Context. https://www.ers.usda.gov/topics/farm-economy/farm-household-well-being/income-and-wealth-in-context/

Pundarik, M. (2002). The Trend of Welfare Disparity among Subgroups of Population in Australia 1983-1984 1993-1994. Applied Economics, 34(4), 1733-1741. https://doi.org/10.1080/00036840210124171

Pundarik, M. (2003). The Ordinal and Cardinal Judgment of Social Welfare Changes in Singapore, 1982-99. The Developing Economies, 41(1), 65-87. https://doi.org/10.1111/j.1746-1049.2003.tb00930.x

Pushkarskaya, H., \& Vedenov, D. (2009). Farming Exit Decision by Age Group: Analysis of Tobacco Buyout Impact in Kentucky. Journal of Agricultural and Applied Economics, 41(3), 653-662. https://doi.org/10.1017/S1074070800003138

Pyatt, G., Chen C., \& Fei J. (1980). The Distribution of Income by Factor Components. Quarterly Journal of Economics, 95(3), 451-473. https://doi.org/10.2307/1885088

Robert, I. L., \& Shlomo, Y. (1989). Improving the Accuracy of Estimates of Gini Coefficients. Journal of Econometrics, 42(1), 43-47. https://doi.org/10.1016/0304-4076(89)90074-2

Samuelson, P. A. (1958). An Exact Consumption-Loan Model of Interest with or without the Social Contrivance of Money. Journal of Political Economy, 66(6), 467-482. https://doi.org/10.1086/258100

Samuelson, P. A. (1977). Reaffirming the Existence of 'Reasonable' Bergson-Samuelson Social Welfare Functions. Economica, 44(73), 81-88. https://doi.org/10.2307/2553553

Sen, A. K. (1997). On Economic Inequality. Expanded Edition. Oxford: Clarendon Press.

Shorrocks, A. F. (1983). Ranking Income Distributions. Economica, 50(197), 3-17. https://doi.org/10.2307/2554117

Skees, J. R., Reed, M. R., \& Pederson, G. D. (1985). Some Distribution Effects of Changing Price Levels on Farm-Level Wealth. North Central Journal of Agricultural Economics, 7(1), 94-104. https://doi.org/10.2307/1349209

Sumner, D. (1982). Off-Farm Labor Participation of Farmers. American Journal of Agricultural Economics, 64(3), 499-509. https://doi.org/10.2307/1240642

Willig, R. D. (1981). Social Welfare Dominance. The American Economic Review, 71(2), 200-204.

Wolff, E. N. (1990). Wealth Holdings and Poverty Status in the U.S. Review of Income and Wealth, 36(2), 143-165. https://doi.org/10.1111/j.1475-4991.1990.tb00277.x

Wunderlich, G. (1984). Fairness in Landownership. American Journal of Agricultural Economics, 66(5), 803-806. https://doi.org/10.2307/1241002 


\section{Appendix A}

\section{Partitioning of social welfare function by age subgroups}

As was described in Podder (1993) and Mukhopadhaya (2002), and as reconstructed to accommodate the objective of this study, the method used to decompose $W$ involves the following steps. First, the ordered vector $x_{T}=x_{1}, x_{2}, \cdots, x_{k}$ into 5 vectors of dimension $n$, with each vector populated by the values $x_{k}^{i}$ of the ith household that corresponds to its kth age group while preserving the original placement of these values as they were in vector $x_{T}$, with zeros being positioned everywhere else. To demonstrate this, let the first vector $x_{1}$ replicates the values of $N W$ for those households headed by individuals aged 35 years or younger, and where the number of households in this cluster is represented by $n_{1}$. Vector $x_{1}$ now has $n_{1}$ values of $N W$ and $n-n_{1}$ zeros. Vectors $n_{2}, \ldots, n_{5}$ are defined in similar manner, which, when concatenated with vector $x_{1}$ allow for the recollecting of vector $x_{T}$ as in:

$$
x_{T}=\sum_{k=1}^{5} x_{k} .
$$

The method of decomposing the social welfare function $(W)$ based on age cohorts requires the formulation of both, the concentration index $\left(C_{k}\right)$ of the elements of vector $x_{k}$, and of the Gini index $(G)$ of vector $x_{T}$ which contains the elements of $N W$ for the whole population of households. In turn, the concentration coefficient $C_{k}$ is defined based on a pseudo Gini index concept as was originally developed by Pyatt et al. (1980) and later augmented by Lerman and Yitzhaki (1985 and 1989) and applied by a number of other studies (see Findeis et al., 1987; Giorgi, 2011) as in:

$$
C_{k}=2 \operatorname{cov}\left[x_{k}, F\left(x_{k}\right)\right] / \bar{x}_{k},
$$

where cov is the covariance function, $\bar{x}_{k}$ is the weighted average of $x_{k}$, and $F\left(x_{k}\right)$ is the ranked, in a non-decreasing order, cumulative distribution of $x_{k}$.

The estimator of $F\left(x_{k}\right)$ in a random sample, as shown in (2), is the rank of $x_{k}$ divided by the sample size $n$. In a weighted sample, as in this study where $v_{i}$ is the inverse of survey weight $w_{i}$ that relates to the ith household and $\sum_{i=1}^{n} v_{i}=1$, the estimator of $F\left(x_{k}\right)$, as noted by Lerman and Yitzhaki (1989), is a mid-interval of $F\left(x_{k}\right)$ or:

$$
\hat{F}_{i}\left(x_{k}\right)=\sum_{j=0}^{i-1} v_{j}+v_{i} / 2 \quad \text { where } \quad v_{0}=0 .
$$

Once the value of $F_{i}\left(x_{k}\right)$ is estimated based on (3), this leads for the direct computatoin of the weighted covariance between $Y_{k}$ and $\hat{F}\left(x_{k}\right)$ as in:

$$
\begin{aligned}
\delta_{k} & =\operatorname{cov}\left[x_{k}, \hat{F}\left(x_{k}\right)\right] \\
& =\sum_{i=1}^{n} v_{i}\left(x_{i, k}-\bar{x}_{k}\right)\left[\hat{F}_{i}\left(x_{k}\right)-\bar{F}\left(x_{k}\right)\right],
\end{aligned}
$$

where $\bar{F}\left(x_{k}\right)$ is the weighted mean of $\hat{F}_{i}\left(x_{k}\right)$.

The weighted concentration coefficient for $x_{k}$ is computed as in:

$$
\mathrm{C}_{k}=2 \delta_{k} / \bar{x}_{k} \text {. }
$$

The weighted partitioning of the Gini index of all sample values of $N W$ (see Podder, 1993; and Mukhopadhaya, 2002) based on the contribution to the disparity in the distribution of wealth by the 5 age cohorts is described by:

$$
G=\sum_{k=1}^{5} \frac{x_{k}}{x_{T}} C_{k} .
$$

To facilitate further the weighted partitioning of the total social welfare function by age cohorts, $x_{T}$ and $x_{k}$ in (1) are presented as follows:

$$
x_{T}=N \bar{x} \quad \text { and } x_{k}=N_{k} \bar{x}_{k},
$$

where $\bar{x}$ is the weighted mean of the population of farm or non-farm households, $N\left(=\sum_{i=1}^{n} w_{i}\right)$ is the weighted total number of all corresponding households, and $N_{k}$ is a subset of $N$ denoting the weighted number of households in the $k^{\text {th }}$ age group. This new representation of $x_{T}$ and $x_{k}$, along with gathering terms, allows (6) to be reformulated as in: 


$$
\bar{x} G=\sum_{k=1}^{5} \frac{N_{k}}{N} \bar{x}_{k} C_{k} .
$$

Trading the sample mean $\mu_{x}$ with the weighted population mean $\bar{x}$, along with using the terms in equations (6) and (8), allows the social welfare function described earlier in section 3 [equation (3)] of the paper to be described as in:

$$
W=\mu_{x}(1-G)=\bar{x}(1-G)=\sum_{k=1}^{5} \frac{N_{k} \bar{x}_{k}}{N}\left(1-C_{k}\right)=\sum_{k=1}^{5} \frac{N_{k}}{N}\left[\bar{x}_{k}\left(1-C_{k}\right)\right]=\sum_{k=1}^{5} \phi_{k},
$$

where $\phi_{k}$ is the absolute share of the kth age category in total social welfare. The relative share of the kth age cohort in total social welfare thus can be evaluated as in:

$$
\varpi_{k}=\frac{\phi_{k}}{W}=\frac{\phi_{k}}{\bar{x}(1-G)} .
$$

From a policy standpoint, the efficacy of a dollar increase in the $N W$ of the kth age group is evaluated based on the marginal impact of such a change in the wealth measure on social welfare as described in the following:

$$
\xi_{k}=\frac{1-C_{k}}{1-G}
$$

In the context of this paper, and as noted by Mukhopadhaya (2002), if the value of $\xi_{k}$ is greater (less) than 1, this shows that a dollar increase in the total $N W$ of the kth age cohort will result in more (less) social welfare than the impact of the dollar rise being expended over the whole society.

\section{Copyrights}

Copyright for this article is retained by the author(s), with first publication rights granted to the journal.

This is an open-access article distributed under the terms and conditions of the Creative Commons Attribution license which permits unrestricted use, distribution, and reproduction in any medium, provided the original work is properly cited. 